\title{
Malignant melanoma metastases to the alimentary tract
}

\author{
A. FRASER-MOODIE, R. G. HUGHES, S. M. JONES, B. A. SHOREY, AND \\ L. SNAPE
}

From the Frenchay Hospital and Bristol Royal Infirmary, Bristol

SUMMARY Seven patients are presented each with symptomatic malignant melanoma metastases to the alimentary tract. Where practicable, surgical excision of the metastases is justified because two patients have had worthwhile periods of survival.

The metastases of malignant melanoma are notorious for appearing many years after the primary and for their myriad clinical manifestations. Even so, symptomatic metastases to the alimentary tract are uncommon. Seven patients are described who presented with alimentary tract lesions which proved to be late metastases from malignant melanoma.

These patients were all initially treated at Frenchay Hospital during the last 20 years. In each case, the primary malignant melanoma of the skin was excised widely, subsequently confirmed histologically, and the defect covered with a split skin graft. The patients were regularly re-examined. However, from two to 12 years later each patient was urgently referred to a general surgeon or physician, usually with symptoms of weight loss, cachexia, and anaemia. The case histories are summarized in the Table.

Two patients (cases 4 and 5) were unfit for surgery and soon died; the diagnosis of metastases in the Received for publication 1 January 1976 bowel of malignant melanoma was made only at necropsy. The other five patients underwent a laporotomy, but the diagnosis was never considered preoperatively. Two patients have had a worthwhile period of survival after resection of the recurrence. One patient (case 7) remained in good health for two years before dying of disseminated disease. Another patient (case 1) is alive and well one year later. Primary malignant melanoma occurs occasionally in the rectum and anal canal, but only rarely elsewhere in the alimentary tract, although, in theory, these tumours could develop throughout the whole of its length. There are 13 reported cases of primary oesophageal melanoma (Raven and Dawson, 1964). Jones (1961) reviewing the literature found six cases of primary melanoma of the gall bladder-a derivative of the foregut. A few malignant melanomas of the small bowel have been reported where the histology suggested secondary spread, but no primary could be found (Willis, 1967).

\begin{tabular}{|c|c|c|c|c|c|c|c|}
\hline Case & $\begin{array}{l}\text { Age } \\
(y r)\end{array}$ & Primary site & $\begin{array}{l}\text { Interval } \\
\text { primary- } \\
\text { metastases } \\
(y r)\end{array}$ & Presenting symptom & GI site & Operation & Survival \\
\hline 1. Mrs P.C. & 55 & Back between & 11 & $\begin{array}{l}\text { Weakness, anaemia, } \\
\text { weight loss }\end{array}$ & Jejunum (3 lesions) & $\begin{array}{l}\text { Resection small } \\
\text { bowel }\end{array}$ & Alive and well 1 \\
\hline 2. Mrs E.B. & 50 & L leg & 9 & $\begin{array}{l}\text { Lower abdominal } \\
\text { pain, melaena }\end{array}$ & Terminal ileum & Resection ileum & $\begin{array}{l}\text { Alive but with pelvic } \\
\text { rec. } 9 / 12 \text { after op. }\end{array}$ \\
\hline 3. Mrs A.B. & 74 & $\begin{array}{l}\text { R parietal } \\
\text { region }\end{array}$ & 10 & Anaemia & $\begin{array}{l}\text { Stomach, small } \\
\text { bowel, colon }\end{array}$ & Biopsy only & Died 4/12 after op. \\
\hline 4. Mr F.C. & 66 & $\mathbf{R}$ heel & 10 & $\begin{array}{l}\text { Weight loss, } \\
\text { vomiting }\end{array}$ & $\begin{array}{l}\text { (PM) Jejunum } \\
\text { (multiple) }\end{array}$ & - & - \\
\hline 5. Mr C.K. & 24 & Behind $\mathbf{R}$ ear & 2 & $\begin{array}{l}\text { Anorexia, weight } \\
\text { loss }\end{array}$ & $\begin{array}{l}\text { (PM) small bowel } \\
\text { (perforated-peritonitis) }\end{array}$ & - & - \\
\hline 6. Mrs M.D. & 41 & R lower leg & 12 & $\begin{array}{l}\text { Jaundice }+ \\
\text { haematemesis } \\
\text { melaena }\end{array}$ & $\begin{array}{l}\text { Involving stomach, } \\
\text { duodenum }+ \\
\text { pancreas }\end{array}$ & $\begin{array}{l}\text { Laparotomy }+ \\
\text { biopsy }\end{array}$ & Died $3 / 12$ after op. \\
\hline 7. Mr A.W. & 39 & $\mathbf{L}$ heel & 2 & Haematemesis & Stomach & Gastrectomy & Died 2 yr after op. \\
\hline
\end{tabular}

Table Clinical details of seven cases of recurrent malignant melanoma to the gastrointestinal tract 


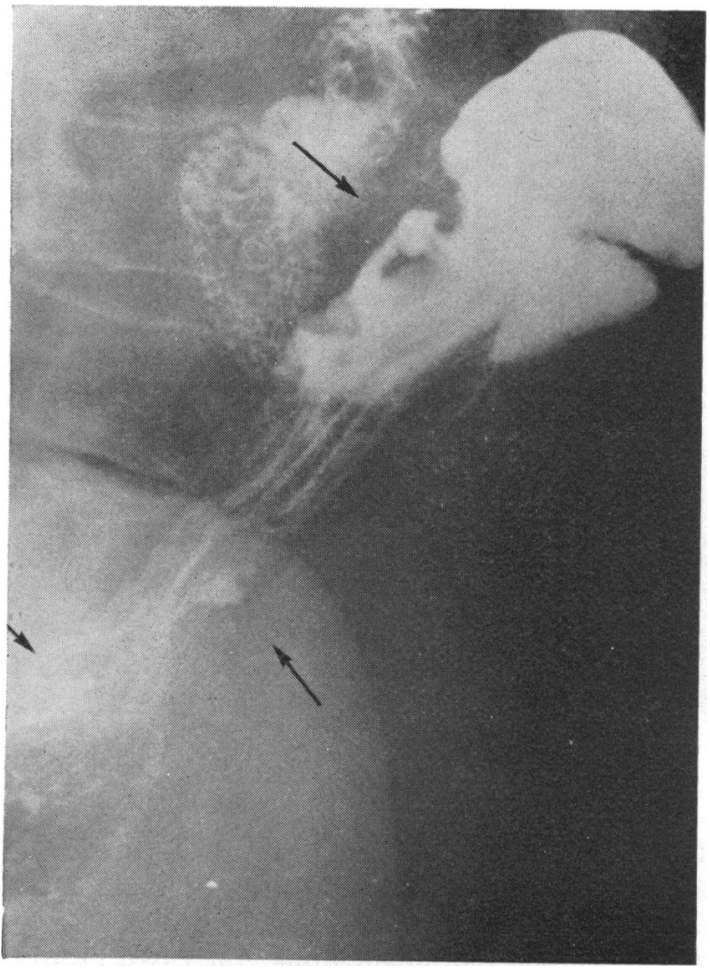

Fig. 1 Case 3. Barium meal, oblique view, arrows indicating barium in gastric ulcer craters.
In 1952 Willis reviewed 135 reported cases of tumour metastases to the small bowel and, of these, malignant melanoma was the commonest of primary origin ( 45 cases). The primary melanoma sites were distant and varied, as in this series, suggesting haematogenous spread (De Castro et al., 1957). Practically all the other tumour metastases originated from primaries within the abdomen or pelvis. The small bowel is the commonest site for alimentary tract metastases from malignant melanoma as in cases 1-6. Gastric malignant melanoma metastases are less common (cases, 3, 6, and 7) and large bowel metastases rare (Harris, 1964). Possibly, metastases in the stomach and small bowel are commoner than in the large bowel because of their relative blood supplies.

Bodenham and Hiles (1971) demonstrated that, in patients with slowly growing malignant melanomata, there was a relatively high titre of antibody to tumour antigen, and a much reduced or absent antibody response in active widely disseminated melanoma. This raises the possibility that melanoma metastases to the small bowel occur in immunologically deficient patients. This concept is supported by the work of Calman (1974) who showed experimentally that implanted lymphoma cells failed to grow in the small intestine of immunologically competent mice but grew in their stomachs. Once these animals were rendered immunologically

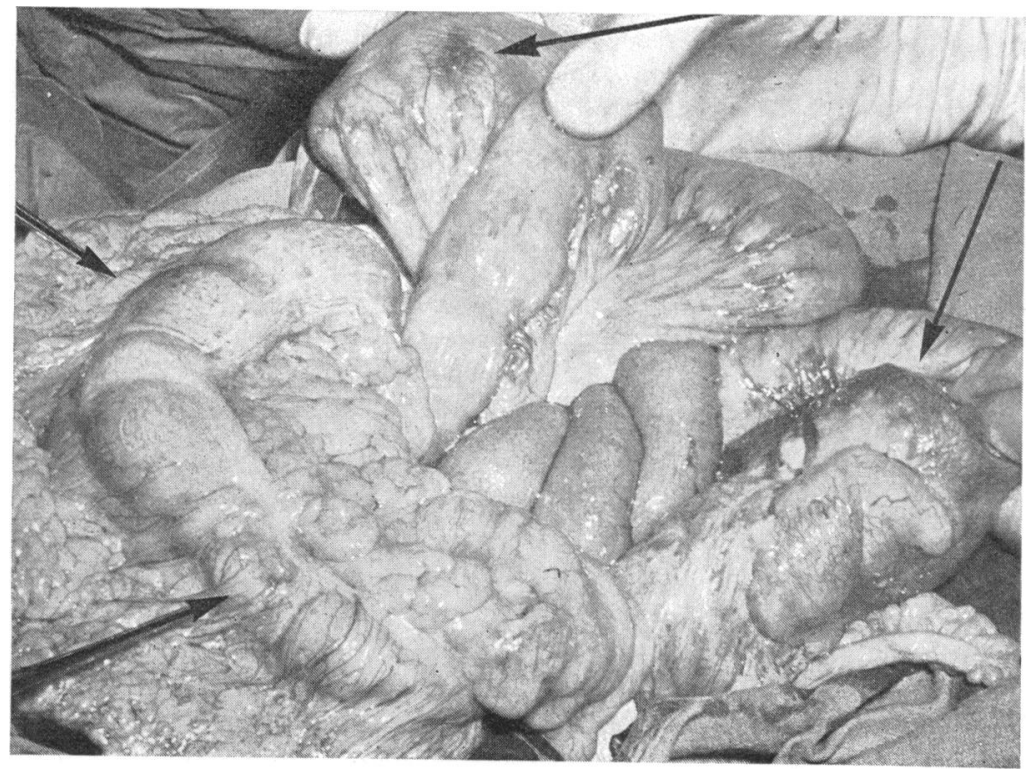

Fig. 2 Case 3. Several malignant melanoma deposits in the small and large bowel as shown by arrows. 


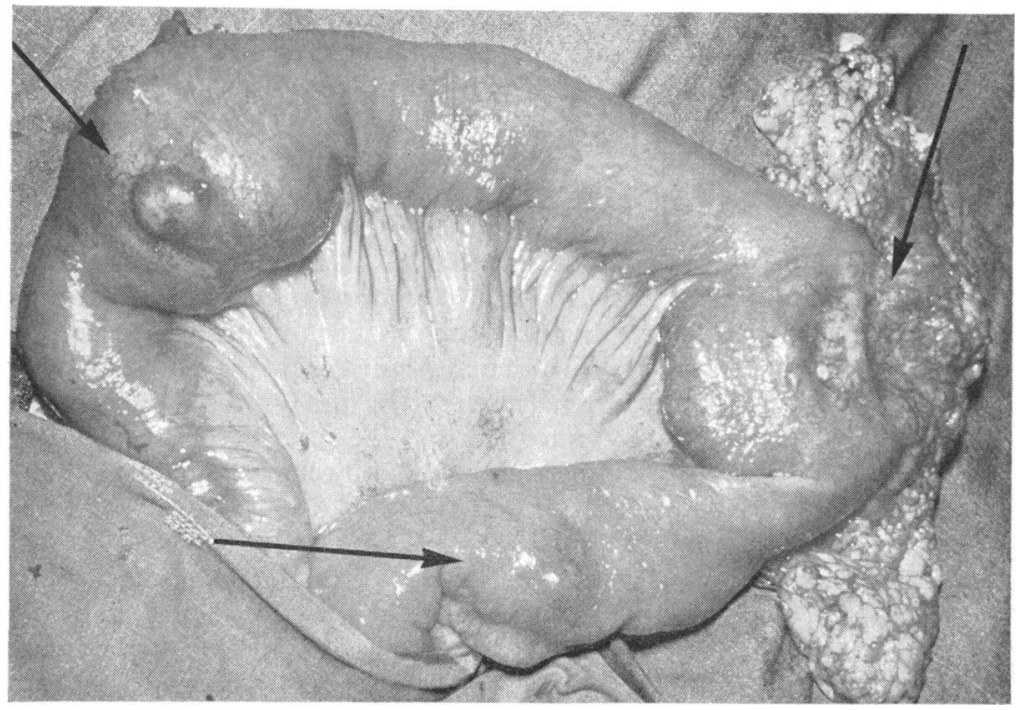

Fig. 3 Case 1. Three secondary deposits of malignant melanoma in the small bowel are pointed out in close proximity. incompetent, such tumours grew in both stomach and small intestine, and he suggested that there might be a local immunological defence mechanism in the small gut. Alimentary metastases of malignant melanoma frequently present with gastrointestinal bleeding, which may be occult as in cases 1 and 3 or acute as in cases 2,6, and 7. Metastases can cause intestinal obstruction by intussusception (Macbeth et al., 1969), while other less common presentations include vague abdominal pain and occasionally malabsorption (Benisch et al., 1972). The diagnosis of recurrent malignant melanoma is rarely considered in the differential diagnosis of occult gastrointestinal bleeding, due to lack of awareness and to the long disease-free interval these patients often display.

Radiographic contrast studies of the bowel are frequently negative (Das Gupta and Brasfield, 1964) but may show ulcers in the stomach (case 3, Fig. 1), or large bowel. Recent improvements in small bowel radiology and mesenteric angiography may improve the preoperative diagnosis in cases of small bowel metastases. Endoscopy can be misleading (as in case 3 when the lesion was thought to be a benign gastric ulcer, but no biopsy was taken). The prognosis in these patients is unpredictable. Multiple deposits make surgical excision impracticable and the outlook correspondingly grave (case 3 , Fig. 2). When the lesion is solitary, as in cases 2 and 7 , or there are several closely related lesions (case 1, Fig. 3) excision is practicable and will deal with the initial problem of haemorrhage. How this affects the prognosis is impossible to say on the available data, but case 7 shows that surgery may well be rewarding.
Macbeth et al. (1969) report a similar case where the patient was alive and well four years later.

Malignant melanoma metastases in the bowel are commoner than one might think. Increased awareness of the problem may lead to earlier diagnosis and better surgical results.

We wish to thank Mr D. C. Bodenham, Mr L. R. Celestin, Mr C. M. Davidson, Dr M. J. Gibson, and Mr R. W. Hiles for permission to publish these cases and illustrations. We also acknowledge the help received from the Melanoma Registry, Frenchay Hospital, supported by a grant from the Empire Cancer Research Campaign.

\section{References}

Benisch, B. M., Abramson, S., and Present, D. H. (1972). Malabsorption and malignant melanoma. Mt. Sinai Journal of Medicine, 39, 474-477.

Bodenham, D C., and Hiles, R. W. (1971). The immunology of melanoma. British Journal of Hospital Medicine, 5, 479-486.

Calman, K. C. (1974). Why are small bowel tumours rare? British Journal of Surgery, 61, 321.

Das Gupta, T. K., and Brasfield, R. D. (1964). Metastatic melanoma of the gastrointestinal tract. Archives of Surgery, 88, 969-973.

De Castro, C. A., Dockerty, M. B., and Mayo, C. W. (1957). Metastatic tumours of the small intestine. Surgery, Gynecology, and Obstetrics, 105, 159-165.

Harris, M. N. (1964). Massive gastrointestinal hemorrhage. Archives of Surgery, 88, 1049-1051.

Jones, C. H. (1961). Malignant melanoma of the gall bladder. Journal of Pathology, 81, 423-430.

Macbeth, W. A. A. G., Gwynne, J. F., and Jamieson, M. G. 
(1969). Metastatic melanoma in the small bowel. Australian and New Zealand Journal of Surgery, 38, 309-315.

Raven, R. W., and Dawson, I. (1964). Malignant melanoma of the oesophagus. British Journal of Surgery, 51, 551-555.
Willis, R. A. (1952). The Spread of Tumours in the Human Body, 2nd edn, p. 212. Butterworths: London.

Willis, R. A. (1967). Pathology of Tumours, 4th edn, p. 932. Butterworths: London.

\section{The February 1976 Issue}

\section{THE FEBRUARY 1976 ISSUE CONTAINS THE FOLLOWING PAPERS}

Hypersensitivity reactions in the small intestine 2. Effects of allograft rejection on mucosal architecture and lymphoid cell infiltrate T. T. MacDONALD AND ANNE FERGUSON

Influence of specific dietary sugars on the jejunal mechanisms for glucose, galactose and $\alpha$-methyl glucoside absorption: evidence for multiple sugar carriers E. S. DEBNAM AND R. J. LEVIN

Immunological studies in patients with Crohn's disease BRUCE R. MACPHERSON, RICHARD J. ALBERTINI, AND WARREN L. BEEKEN

Gastrointestinal involvement in systemic mastocytosis R. W. AMMANN, D. VETTER, P. DEYHLE, H. TSCHEN, H. SULSER, AND M. SCHMID

Nutrition in cryptogenic cirrhosis and chronic aggresive hepatitis A. G. MORGAN, J. KELLEHER, B. E. WALKER, AND M. S. LOSOWSKY

Hepatitis-B surface antigen and cirrhosis in Iraq E. H. BOXALl, T. H. FLEWETT, A. PATON, AND S. W. RASSAM

Relationship of splanchnic blood flow and portal venous resistance to elevated portal pressure in the dog C. L. WITTE, G. R. TOBIN, D. S. CLARK, AND M. H. WITTE
Hyperamylasaemia after duodenoscopy and retro. grade cholangiopancreatography G. SKUDE, LWEHLIN, T. MARUYAMA, AND J. ARIYAMA

Effect of cimetidine on 24-hour intragastric acidity in normal subjects R. E. POUNDER, J. G. WILLIAMS, G. J. MILTON-THOMPSON, AND J. J. MISIEWICZ

Absorption of propranolol and practolol in coeliac disease R. L. PARSONS, C. M. KAYE, K. RAYMOND, J. R. TROUNCE, AND P. TURNER

Relationship of serum gastrin response to lower oesophageal sphincter pressure J. DENT AND J. HANSKY

Function of the anal sphincters in patients with intussusception of the rectum B. FRENCKNER AND T. IHRE

Potassium status of patients with cirrhosis N. G. SOLER, S. JAIN, H. JAMES, AND A. PATON

\section{Technique}

Paediatric small intestinal biopsy capsule with two ports ANNE KILBY

Notes and activities

Copies are still available and may be obtained from the PUBLISHING MANAGER, BRITISH MEDICAL ASSOCIATION, TAVISTOCK SQUARE, LONDON WC1H 9JR, price $£ 2 \cdot 00$, including postage 